\title{
Efek Pemberian Infusa Biji Labu Kuning (Cucurbita Moschata Durch) Terhadap Cacing Fasciola Sp Secara In Vitro
}

\section{The Effect Of Giving Yellow Mosquito Seed Infusion (Cucurbita Moschata Durch) On Fasciola Sp In Vitro}

\author{
Pramu, Rendi Dian Putra, Abu Zaenal Zakariya \\ Politeknik Pembangunan Pertanian Yogyakarta-Magelang \\ Jl. Magelang Kopeng Km 7, Tegalrejo, Magelang \\ email: rendi14198@gmail.com
}

Diterima : 6 Februari 2020

Disetuju : 30 Maret 2020

\begin{abstract}
ABSTRAK
Peningkatan produksi dan reproduksi ternak akan optimal jika penyediaan pakan yang memadai dan pengendalian penyakit dilakukan secara efektif. Gangguan penyakit pada ternak dapat menurunkan produktivitas ternak. Penyakit yang biasanya menyerang ternak sapi adalah penyakit cacing. Penyakit ini tidak mengakibatkan kematian pada ternak, namun menyebabkan kerugian yang sangat besar karena menurunkan berat badan dan daya produktivitas hewan. Biji labu kuning telah lama digunakan sebagai antihelmintik. Penentuan efektivitas biji labu kuning sebagai obat cacing, maka dilakukan penelitian dengan memasukkan cacing sebanyak 10 ekor ke dalam cawan petri yang berisi infusa biji labu kuning dengan konsentrasoi yang berbeda, yaitu (P1): konsentrasi kandungan infusa biji labu kuning 25/100 ml, (P2): konsentrasi kandungan infusa biji labu kuning 50/100 ml, dan (P3): konsentrasi kandungan infusa biji labu kuning 75/100 ml. Hasil penelitian menunjukkan bahwa dengan konsentrasi infusa labu kuning sebesar $75 \%$ mampu membunuh semua cacing fasciola yang ada. Konsentrasi yang lebih rendah menunjukkan angka kematian sebesar $47 \%$ dan $77 \%$. Dengan demikian dapat direkomendasikan bahwa penggunaan infusa labu kuning sebesar 75/100 ml.
\end{abstract}

Kata Kunci: cacing hati, biji labu, produksi ternak

\begin{abstract}
Increasing livestock production and reproduction will be optimal if adequate feed and disease control are carried out effectively. Disorders of disease in livestock can reduce livestock productivity. The disease that usually attacks cattle is worm disease. This disease does not cause death in the animal but causes enormous losses due to weight loss and low animal productivity. Pumpkin seeds have long been used as anthelmintic. Determination the effectiveness of pumpkin seeds as a worm medicine, a study was conducted by putting ten worms into a petri dish containing pumpkin seed infusion with different concentrations, (P1): concentration of 25/100 ml pumpkin seed infusion, (P2): concentration of pumpkin seed infusion
\end{abstract}


content of 50/100 ml, and (P3): concentration of pumpkin seed infusion content of $75 / 100 \mathrm{ml}$. The results showed that with a pumpkin infusion concentration of $75 \%$ could kill all the existing fasciola worms. Lower concentrations indicate mortality rates of $47 \%$ and $77 \%$. Thus it can be recommended that the use of $75 / 100 \mathrm{ml}$ pumpkin infusion.

Keywords: fasciola sp, pumpkin seeds, livestock production

\section{PENDAHULUAN}

Gangguan penyakit pada ternak merupakan salah satu hambatan yang di hadapi dalam pengembangan peternakan. Peningkatan produksi dan reproduksi akan optimal bila secara simultan disertai penyediaan pakan yang memadai dan pengendalian penyakit yang efektif. Salah satu penyakit parasitik yang biasanya menyerang ternak sapi adalah penyakit cacing. Penyebab cacingan pada ternak sapi antara lain karena mengonsumsi hijauan yang masih mengandung embun, yang menjadi vektor parasit cacing. Penyakit ini tidak mengakibatkan kematian ternak, namun menyebabkan kerugian yang sangat besar karena menurunkan berat badan dan daya produktivitas hewan. Penyakit parasit yang sangat merugikan adalah penyakit yang disebabkan oleh cacing hati fasciola hepatica, yang dikenal dengan nama distomatosis, atau fasciolosis.

Disamping itu, perlunya dilakukan usaha pengendalian penyakit dengan melakukan pemberian obat cacing secara rutin pada ternak. Namun untuk obat yang dipakai hendaknya menggunakan bahan alami. Biji labu kuning telah lama digunakan dalam pengobatan masyarakat cina dan suku indian di amerika sebagai antihelmintik terhadap askariasis, cestodiasis serta skistomiasis. Efek antihelmintik biji labu kuning berasal dari kandungan zat aktifnya, yaitu tannin, yang bekerja dengan cara menggumpalkan protein pada dinding cacing, sehingga menyebabkan gangguan metabolisme dan homeostasis cacing, serta cucurbitine yang bekerja sebagai antagonis asetilkolin, menekan kontraksi otot polos, sehingga cacing mengalami paralisis spastik. Diharapkan dengan menulis judul "Efek Pemberian Infusa Biji Labu Kuning (Cucurbita moschata Durch) Terhadap Cacing Fasciola $S p$ Secara In Vitro" peneliti dapat mengetahui seberapa efektifnya penggunaan biji labu kuning sebagai anthelmintik.

Berdasarkan hasil pengkajian inovasi yang telah dilaksanakan sebelumnya, maka permasalahan yang dapat dirumuskan adalah Belum diketahuinya kandungan dari biji labu kuning (Cucurbita moschata Durch) terhadap cacing fasciola $\mathrm{sp}$, dan belum diketahuinya tingkat mortalitas terhadap cacing fasciola sp secara in vitro.

Adapun tujuan yang ingin dicapai pada pengkajian inovasi adalah mengetahui kandungan dari biji labu kuning (Cucurbita moschata Durch) terhadap cacing fasciola sp, dan mengetahui tingkat mortalitas terhadap cacing fasciola sp secara in vitro.

Cacing Fasciola sp. berwarna coklat abu-abu dengan bentuk seperti daun, pipih, melebar dan lebih melebar ke anterior dan berakhir dengan tonjolan berbentuk conus. Ukuran tubuh cacing dewasa dapat mencapai panjang 30 $\mathrm{mm}$ dan lebarnya $13 \mathrm{~mm}$. Telur cacing berbentuk lonjong, berukuran panjang 130-150 mikron dan lebar 63-90 mikron. 
Selain itu terdapat arterium yang letaknya di bawah penis dan esofagus, uterus, vasikula seminalis, ovarium serta oviduk pada hewan ini (Kaiser, 2012).

Fasciola sp. mengalami mata rantai siklus perkembangan atau stadium dalam siklus hidupnya sampai ke saluran empedu. Cacing dewasa memproduksi telur dan keluar bersama tinja. Cacing Fasciola sp. dapat hidup sekitar satu tahun di dalam tubuh ternak. Cacing ini akan memakan jaringan hati dan darah pada saat masih muda, dan makanan utama setelah dewasa adalah darah (Martindah dkk., 2005).

Fasciola hepatica merupakan cacing hati yang diduga masuk ke Indonesia bersama-sama dengan sapisapi yang didatangkan dari luar negeri. Pada umumnya infeksi Fasciola sp. menyerang sapi, domba dan kambing berkisar antara $50-80 \%$ untuk sapi dan kerbau di pulau Jawa dan dibawah 10\% untuk pulau Sumba. Telur Fasciola juga berhasil ditemukan pada sampel tinja badak Jawa dari Suaka Marga Satwa Ujung Kulon (Pangihutan, 2007).

Labu kuning merupakan jenis tanaman musiman (annual) dari Famili Cucurbitaceae. Tanaman labu kuning dapat tumbuh di dataran tinggi maupun rendah sehingga mudah dijumpai di Indonesia (Arza dan Asmira, 2017). Ketinggian tempat ideal untuk menanam labu kuning adalah antara $0-1500$ mdpl. Terdapat lima spesies labu kuning yang umum dikenal, yaitu Cucurbita maxima Duchenes,Bouche, Cucurbita mixta, Cucurbita moschata Duchenes dan Cucurbita pipo L (Brotodjojo, 2010). Tanaman ini tumbuh secara luas di seluruh dunia dan merupakan tanaman sayuran menjalar semusim yang akan mati setelah berbuah. Labu kuning dapat tumbuh di dataran rendah maupun dataran tinggi dengan ketinggian antara $0 \mathrm{~m}-1.500 \mathrm{~m}$ di atas permukaan laut. Biji labu kuning berbentuk oval pipih dan belum dimanfaatkan secara maksimal oleh masyarakat sehingga dibuang sebagai limbah (Patel 2013).

Labu kuning (Cucurbita moschata) termasuk ke dalam dunia Plantae, filum Spermatophyta, subfilum Angiospermae, kelas Dicotyledonae, Ordo Violales, family Cucurbitaceae, dan genus Cucurbita (CABI 2017).

Biji labu merupakan sumber protein alami, pitosteron, asam lemak tak jenuh, sterol, vitamin dan antioksidan seperti karotenoid dan tokoferol (Mohammadi dkk., 2014). Senyawa metabolit sekunder yang terkandung dalam biji labu kuning (C.moschata Durch.) adalah flavonoid, senyawa alkaloid, senyawa fenol, senyawa terpenoid, senyawa steroid dan senyawa saponin. Biji labu kuning telah lama digunakan dalam pengobatan masyarakat cina dan suku indian di amerika sebagai antihelmintik terhadap askariasis, cestodiasis serta skistomiasis (Koike dkk., 2005). Secara tradisional biji labu kuning dijadikan sebagai obat kecacingan terutama cacing pita. Dengan dosis biji segar setelah ditumbuk dengan air dijadikan emulsi, diminum sekaligus untuk mengobati cacing pita. Serbuk biji yang telah dikeringkan digunakan untuk mengobati schistomiasis.

Anthelmintik adalah senyawa kimia yang menghancurkan atau mengeluarkan cacing dari saluran pencernaan atau organ dan jaringan yang mereka tempati di dalam inang (Permin and Hansen, 1998). Anthelmintik sebagai obat yang digunakan untuk memberantas atau mengurangi parasit cacing di dalam lumen usus atau jaringan tubuh. Anthelmintik yang ideal adalah memiliki spektrum yang luas, tidak toksik, batas keamanan yang tinggi, cepat dimetabolisme, mudah diaplikasikan dan biaya murah. 
Kebanyakan obat cacing efektif terhadap satu macam cacing, sehingga diperlukan diagnosis tepat sebelum menggunakan obat tertentu. Kebanyakan obat cacing diberikan secara oral, pada saat makan atau sesudah makan. Beberapa obat cacing perlu diberikan bersamaan dengan pencahar. Obat cacing baru umumnya lebih aman dan efektif dibanding dengan yang lama, efektif untuk beberapa macam cacing, rasanya tidak mengganggu, pemberiannya tidak memerlukan pencahar dan beberapa dapat diberikan secara oral sebagai dosis tunggal (Departemen Farmakologi dan Terapeutik, 2007).

Biji labu kuning secara tradisional telah lama digunakan sebagai anthelmintik dalam pengobatan tradisional oleh masyarakat Cina dan suku Indian di Amerika Utara. Biji labu kuning mengandung asam amino cucurbitine yang terdapat dalam biji labu kuning merupakan agen aktif sebagai anticacing, antioksidan, antikanker, dan efek kardiovaskular

Efek anthelmintik dari biji labu kuning (Cucurbita moschata Durch) berasal dari senyawa kimia, diantaranya adalah senyawa tannin dan cucurbitin. Tannin berfungsi untuk menggumpalkan protein pada dinding tubuh cacing sehingga menyebabkan gangguan metabolisme dan homeostatis pada cacing. Cucurbitin bekerja melalui respon asetilkolin yang menekan kontraksi otot polos sehingga melumpuhkan cacing hingga kejang sampai mati (Hamed dkk., 2008).

Anthelmintik adalah senyawa kimia yang menghancurkan atau mengeluarkan cacing dari saluran pencernaan atau organ dan jaringan yang mereka tempati di dalam inang (Permin and Hansen, 1998). Anthelmintik sebagai obat yang digunakan untuk memberantas atau mengurangi parasit cacing di dalam lumen usus atau jaringan tubuh.
Anthelmintik yang ideal adalah memiliki spektrum yang luas, tidak toksik, batas keamanan yang tinggi, cepat dimetabolisme, mudah diaplikasikan dan biaya murah. Antisipasi masalah di atas, perlu dikembangkan anthelmintik yang berasal dari tanaman obat (herbal) dengan harga yang relatif murah dan mudah didapat (Siska, 2008).

\section{MATERI DAN METODE}

\section{Waktu dan Tempat}

Waktu pelaksanaan kajian inovasi teknologi dilakukan pada tanggal 22-25 Januari 2020 di Laboratorium Kesehatan Hewan Politeknik Pembangunan Pertanian YogyakartaMagelang Jurusan Peternakan.

\section{Alat dan Bahan}

Alat yang digunakan dalam pengkajian diantaranya cawan petri berdiameter $15 \mathrm{~cm}$, batang pengaduk kaca, pinset anatomis, beaker glass, timbangan, saringan, botol, label dan spidol. Bahan yang digunakan dalam kajian diantaranya Cacing Fasciola $s p$ dan biji labu kuning.

\section{Rancangan Kajian}

Rancangan yang digunakan dalam penelitian ini yaitu Rancangan Acak Lengkap (RAL), yang terdiri dari perlakuan 4 dengan 3 ulangan, sehingga bahan yang digunakan sebanyak 40 ekor dan masing-masing perlakuan menggunakan 10 ekor, untuk perlakuan (P1): dimasukan kedalam cawan petri yang berisi infusa biji labu dengan konsentrasi 25 / 100 ml, (P2): dimasukan kedalam cawan yang berisi infusa biji labu kuning dengan konsentrasi $50 / 100 \mathrm{ml}$, sedangkan untuk perlakuan (P3): dimasukan kedalam cawan yang berisi infusa biji labu kuning dengan konsentrasi 75 / $100 \mathrm{ml}$. 
Pelaksanaan pembuatan Infusa biji labu kuning diperoleh dari penggumpulan biji labu kuning yang diambil dari buah labu kuning. Biji buah labu kuning dicuci, Kemudian biji labu kuning di jemur selama 3 hari dibawah sinar matahari. Setelah kering, biji labu kuning dimasukkan ke dalam mesin penggiling dan digiling menjadi serbuk dan kemudian dilakukan pengayakan. Hasil pengayakan ini yang akan digunakan sebagai bahan pembuatan infusa. Pembuatan infusa dilakukan dengan menimbang serbuk biji labu kuning sesuai dengan konstrasi lalu tambahkan akuades $100 \mathrm{ml}$ dan dimasukkan ke dalam beaker glass, kemudian dipanaskan di penangas air pada suhu $90{ }^{\circ} \mathrm{C}$ selama 15 menit sambil sesekali diaduk, kemudian disaring dengan kain dan ditampung dalam botol. Apabila belum di dapatkan volume $100 \mathrm{ml}$ maka ditambahkan akuades di atas bahan yang disaring sampai didapatkan volume $100 \mathrm{ml}$.

\section{Variabel Pengamatan}

Variabel pengamatan yang diamati dalam pengkajian ini yaitu kematian fasciola $\mathrm{sp}$ dan kepekaan cacing terhadap larutan yang diuji merupakan variabel luar yang tidak dapat dikendalikan.

\section{Analisis Data}

Analisis data dilakukan dengan deskriptif dan statistik. Adapun yang dimaksud dengan analisis deskriptif untuk mengetahui keberadaan variabel tanpa membuat perbandingan dan mencari hubungan variabel itu dengan variabel yang lain. Sedangkan analisis statistik dilakukan dengan membandingkan Lethal Death Time antara cacing yang diberi perlakuan infusa biji labu kuning. Data selanjutnya diolah dengan menggunakan sidik (ANOVA) dan diuji dengan Uji Duncan.

\section{HASIL DAN PEMBAHASAN}

\section{Kandungan Biji Labu Kuning}

Hasil analisa laboratorium UGM menunjukkan bahwa kandungan tannin pada biji labu kuning adalah sebesar 34,53.\%. Hal ini menunjukan bahwa kandungan tannin sangat cocok digunakan sebagai anthelmintik. Menurut Hson (2001) efek biji labu kuning berasal dari kandungan zat aktifnya yaitu tannin, yang bekerja dengan cara menggumpalkan protein pada dinding cacing, sehingga menyebabkan gangguan metabolisme dan homeostasis cacing, serta cucurbitine. (kandungan per 100 gram ekstrak biji labu kuning mencapai $22,8 \%$ bekerja sebagai antagonis asetilkolin, menekan kontraksi otot polos, sehingga cacing mengalami paralisis spastik hingga akhirnya mati. Hasil analisis menunjukkan bahwa kandungan tanninnya cukup tinggi dan sangat efektif jika digunakan sebagai antihelmintik.

\section{Mortalitas Cacing Secara In Vitro}

Pengujian mortalitas cacing dilakukan secara in vitro yang digunakan adalah fasiciola sp yang dapat ditemukan pada bagian hati sapi. Penelitian ilmiah terhadap efek antihelmintik biji labu kuning telah dilakukan secara in vitro. Menurut Siswarini dkk., (2017) Uji Efektifitas Daya Anthelmintik Infusa Biji Labu Kuning (Cucurbita moschata Durch) Terhadap Cacing Fasciola gigantica Secara In Vitro.

Pengujian ini dilakukan menggunakan 3 pengulangan, hasil pengujian mortalitas cacing dapat dilihat pada tabel 1. Pengujian dilakukan untuk menemukan tingkat mortalitas yang paling efektif pada cacing fasciola $s p$ pada ternak sapi. Persentase mortalitas cacing fasciola sp pada ternak sapi dapat dilihat pada tabel 1 dibawah ini : 
Tabel 1. Rerata mortalitas cacing fasciola sp pada perlakuan infusa biji labu kuning.

\begin{tabular}{lccc}
\hline $\begin{array}{c}\text { Pengulangan } \\
\text { Pengujian }\end{array}$ & $\begin{array}{c}\text { Dosis } \\
25 \%\end{array}$ & $\begin{array}{c}\text { Dosis } \\
50 \%\end{array}$ & $\begin{array}{c}\text { Dosis } \\
75 \%\end{array}$ \\
\hline 1 & $40 \%$ & $80 \%$ & $100 \%$ \\
2 & $50 \%$ & $70 \%$ & $100 \%$ \\
3 & $40 \%$ & $80 \%$ & $100 \%$ \\
\hline Rata-Rata & $47 \%$ & $77 \%$ & $100 \%$
\end{tabular}

Sumber: Data Terolah, 2020

Pada Tabel 1 di atas dapat dilihat dari ketiga kali pengulangan yang dilakukan mendapatkan rerata bahwa pemberian infusa biji labu kuning memiliki nilai yang bervariatif. Pada perlakuan pertama dengan menggunakan dosis $25 \%$ didapatkan rata-rata tingkat mortalitas dari cacing adalah $47 \%$. Pada perlakuan kedua dengan menggunakan dosis $50 \%$ didapatkan rerata tingkat mortalitas cacing adalah $77 \%$ sedangkan pada perlakuan ketiga dengan menggunakan dosis $75 \%$ didapatkan rerata tingkat mortalitas cacing adalah $100 \%$ pada jam ke 6 mempunyai kematian tertinggi sehingga dapat dijadikan anthelmintik. Dari hasil ini dapat disimpulkan bahwa dari ketiga dosis yang telah dilakukan pengujian secara in vitro didapatkan bahwa dosis tertinggi yang dapat mematikan cacing adalah dosis 75 gram.

\section{Analisis Data}

Hasil pengujian mortalitas cacing terhadap pemberian bubuk biji labu kuning menggunakan analisis statistik dengan perolehan hasil analisis mortalitas cacing dapat dilihat pada tabel 2.

Tabel 2. Mortalitas cacing fasiciola $s p$ pemberian infusa biji labu kuning setelah jam 6

\begin{tabular}{lr}
\hline Perlakuan & Hasil rerata \\
\hline $25 \%$ & $4.33 \pm 5.77^{\mathrm{c}}$ \\
$50 \%$ & $7.67 \pm 5.77^{\mathrm{b}}$ \\
$75 \%$ & $10.00 \pm .000^{\mathrm{a}}$ \\
\hline
\end{tabular}

Sumber: Data Terolah, 2020
Keterangan: a,b,c, Superskrip yang berbeda pada kolom yang sama menunjukan perbedaan yang sangat nyata $(P<0,01)$

Hasil ini membuktikan bahwa pemberian infusa biji labu kuning setelah jam ke enam memiliki dampak yang sangat nyata dalam membunuh cacing. Berdasarkan hasil tersebut maka dapat disimpulkan bahwa penggunaan biji labu dengan dosis 75 $\%$ dapat dijadikan sebagai anthelmintik dan dapat digunakan untuk menggantikan penggunaan obat kimia yang beredar dipasaran.

\section{KESIMPULAN}

\section{Simpulan}

Berdasarkan kajian inovasi teknologi yang telah dilakukan maka dapat ditarik kesimpulan bahwa Perlakuan yang ketiga dengan dosis sebesar $75 \%$ merupakan formula terbaik untuk dijadikan sebagai anthelmintik karena memiliki tingkat mortalitas tinggi terhadap cacing fasciola sp dengan persentase sebesar $100 \%$ dan tingkat kematian cacing dengan perlakuan infusa biji labu kuning dosis $75 \%$ jauh lebih tinggi dari yang lainnya. Perlakuan tersebut ternyata memiliki pengaruh nyata $(P>0,05)$ sehingga dosis $75 \%$ dapat digunakan sebagai anthelmintik.

\section{Saran}

Diharapkan dalam pengkajian yang sudah dilakukan ini supaya dapat dikaji kembali oleh pihak lain untuk memperdalam ilmu pengetahuan mengenai efek anthelmintik yang terdapat pada biji labu kuning.

\section{DAFTAR PUSTAKA}

Arza, P.A dan S. Asmira. 2017. Pengaruh Penambahan Labu 
Kuning (Cucurbitamoschata) dan Ikan Gabus (Ophiocephalus striatus) terhadap Mutu Oragnoleptik, Kadar Protein an Vitamin A Biskuit. Nutrisains, I (1) $: 1-9$

Brotodjojo, L C., 2010, Semua Serba Labu Kuning, Gramedia Pustaka Utama, Jakarta.

Center of Agriculturre and Biosciences International(CABI). 2017. Cucurbita moschata (pumpkin) [internet]. Diakses pada tanggal 19

September

2019.https://www.cabi.org/isc/dat asheet/17068

Departemen Farmakologi dan Terapeutik FK UI. 2007. Farmakologi dan Terapi Edisi 5. Jakarta: Bagian Farmakologi FK Ul.

Hamed SY, Hassan AB, Eltayeb MM and Babiker EE. 2008. Nutritional Evaluation and Physiochemical Properties Of Processed Pumpkin Seed Flour. Pakistan Journal Of Nutrition. 7(2) : 330334.

Hendrasty, HK. 2003. Tepung Labu Kuning. Kasinus, Yogyakarta.

Hson.M.C, Paul PH dan SIH C.Y.2001.Pharmacology dan applications of Chinese dan Material Medical. Singapore. World Scientific.hal 832. Journal of Nutrition and Metabolism. Vol 6 (3) : 183-189

Kaiser, Gary E. 2012. The Liver Fluke Fasciola hepatica trematode (http://faculty.ccbcmd.edu/course s/bio141/labmanua/lab20/lfluke.ht $\mathrm{ml}$ ) diakses pada tanggal 25 Januari 2020).

Koike K, Wei L, Liu L.J. Hata E dan dan Nikaido T. 2005. New phenolye glycosides from the seeds of cucurbita moschata. Chem, pham. Bull. 53 (2):225-228

Martindah E., Widjajanti S., Estuningsih S.E., dan Suhardono. 2005.
Meningkatkan Kesadaran dan Kepedulian Masyarakat Terhadap Fascioliasis Sebagai Penyakit infeksius. Wartazoa Vol. 15.

http://www.petemakan.litbang.de ptan.go.id. Diakses pada tanggal 25 Januari 2020.

Mohammadi, F., Nikzad, H., Taherian, A., Taghizadeh, M., Tiameh, A.A.,Naderian, H., and M.A. Atlasi. 2014. Combined Effect of Ginger and Pumpkin Seed Extracts on Rat Testis and Serum Biochemical Parameters after Cyclophosphamide Treatment. Anatomical Sciences. Vol 11 (1) : 33-40

Pangihutan J. 2007. Telur Cacing Trematoda pada Tinja Badak Jawa (Rhinoceros sondaicus) di Taman Nasional Ujung Kulon. [skripsi]. Bogor: Fakultas Kedokteran Hewan, Instutut Pertanian Bogor

Patel, S. 2013. Pumpkin (Cucurbita sp.) seeds as nutraceutic. Mediterranean

Permin, A., P. Hansen, M. Bisgaard, Frandsen, and M. Pearman. 1998. Studies on Ascaridia galli in chickens kept at different stocking rate. J. of Avian Pathology 27: 382-389.

Siska F. 2008. Penapisan Fitokimia Dan Uji Aktivitas Anthelmintik Ekstrak Daun Jarak (Jatropha curcas L.) Terhadap Cacing Ascaridia galli Secara in Vitro [Skripsi]. Fakultas IImu Nutrisi Dan Makanan Ternak. Institut Pertanian Bogor.

Siswarini, A.D., Kustono., dan R. Bijanti. 2017. Uji Efektifitas Daya Anthelmintik Infusa Biji Labu Kuning (Cucurbita moschata Durch.) terhadap Cacing Fasciola gigantica secara In Vitro. Journal of Parasite Sciense. Vol 1 (1) : 710 
